\title{
DETERMINAN STUNTING ANAK 6 - 24 BULAN DI KABUPATEN TIMOR TENGAH SELATAN
}

\author{
Suriana Koro ${ }^{1}$, Veni Hadju ${ }^{2}$, Suryani As'ad ${ }^{3}$, Burhanuddin Bahar ${ }^{2}$ \\ 1. Politekhnik Kesehatan Kemenkes Kendari \\ 2. Fakultas Kesehatan Masyarakat Unhas \\ 3. Fakultas Kedokteran Unhas
}

\begin{abstract}
ABSTRAK
Latarbelakang Secara nasional prevalensi stunting pada balita di Indonesia adalah 37,2\%. Hal ini berarti bahwa masalah gizi di Indonesia masih merupakan masalah kesehatan masyarakat yang serius Sementara proporsi balita stunting 48,2\% di Provinsi NTT termasuk masalah kesehatan masyarakat yang kritis. Penelitian ini bertujuan untuk mengetahui determinan stunting anak 6 - 24 bulan di Kabupaten Timor Tengah Selatan Propinsi Nusa Tenggara Timur. Penelitian ini merupakan penelitian observasional dengan rancangan potong lintang, dilaksanakan di Sembilan wilayah kecamatan Kabupaten Timor Tengah Selatan. Data konsumsi makanan baduta diperoleh melalui recall konsumsi, sedangkan data lainnya diperoleh melalui kuisioner oleh tenaga enumerator. Analisis zat gizi pada makanan menggunakan food processor 2 (FP2). Uji statistik yang digunakan adalah chi-Square.Jumlah responden yang diteliti sebanyak 3480 anak, yang stunting dan severe stunting sebanyak 1416 anak (40,7\%), sebagian besar adalah laki-laki sebanyak 1870 anak (53,7\%), untuk umur 12 - 24 bulan sebanyak 1916 anak $(55,1 \%)$, dimana hasil uji chi square signifikan $\mathrm{p}<0,05$. Pendidikan ibu dan bapak masing-masing 1827 orang $(52,5 \%)$ dan 1754 orang $(50,4 \%)$ berpendidikan dasar tidak tamat dan tamat SMP dengan pekerjaan yang mayoritas petani ibu(83,3\%) dan bapak (65,0\%), sosial ekonomi sebagian besar tergolong rendah $(83,5 \%)$. TB ibu bermakna secara signifikan $(\mathrm{p}=0,000)$ begitupun dengan paritas dan jarak kelahiran diperoleh hasil uji chi-square bermakna secara signifikan $\mathrm{p}<0,005$, sementara memberikan ASI Eksklusif hanya 596 orang $(17,1 \%)$ Kebutuhan zat gizi tidak mencapai Recommended dieatery allowanced (RDA) $<80 \%$ AKG, asupan energy $(90,3 \%)$, protein $(82,6 \%)$, Lemak $(97,9 \%)$ dan KH $(82,0 \%)$. Riwayat penyakit diare $(17,4 \%)$, demam $(32,6 \%)$, sesak $(2,3 \%)$, batuk $(31,0 \%)$ dan beringus $(29,2 \%)$ dan hasil uji chisquare hanya demam yang bermakna dengan $\mathrm{p}=0,016$. Hasil logictic regresi diperoleh faktor jenis kelamin dan tinggi ibu yang paling berhubungan dengan status gizi stunting. Kesimpulan: faktor determinan stunting adalah usia anak, jenis kelamin, pendidikan ibu, pekerjaan ibu, tinggi ibu, paritas, jarak kelahiran, asupan protein dan riwayat penyakit demam.

Kata Kunci : Stunting, anak usia 6 -24 bulan
\end{abstract}

\section{PENDAHULUAN}

\section{Latar Belakang Masalah}

Stunting menimbulkan berbagai konsekuensi, baik yang bersifat jangka pendek maupun jangka panjang. Pada jangka pendek stunting, wasting berat, dan IUGR secara bersama-sama bertanggungjawab pada kematian 2.2 juta kematian anak balita dan $21 \%$ disability-adjusted life-years (DALYs). Untuk jangka panjang, analisis data pada 5 negara berpendapatan rendah-sedang menunjukkan bahwa stunting pada masa anak berkorelasi kuat dengan postur pendek saat dewasa, rendahnya kehadiran di sekolah, berkurangnya fungsi intelektual, dan rendahnya berat lahir keturunannya nanti (Black et al. 2008).

Masalah gizi pada balita masih merupakan masalah kesehatan masyarakat (public health problem) jika prevalensi pendek(stunting) >20\% (UNHCR, 2011). Prevalensi stunting secara umum didunia juga termasuk pada masalah kesehatan masyarakat karena masih sebesar 26\% (WHO, 2012). Secara nasional prevalensi stunting pada balita di Indonesia 
Health Information: Jurnal Penelitian ISSN xxxx-xxxx

http://myjurnal.poltekkes-kdi.ac.id

adalah 37,2\% . Hal ini berarti bahwa masalah gizi di Indonesia masih merupakan masalah kesehatan masyarakat yang serius (Riskesda 2013).

Prevalensi stunting $(27,5 \%)$ provinsi Nusa Tenggara Timur (NTT) merupakan salah satu yang tertinggi di Indonesia (Profil Kesehatan Indonesia 2012). Sementara hasil Riskesda 2013, mendapatkan proporsi balita stunting sebanyak 48,2\%.

Malnutrisi masih merupakan satu masalah yang paling umum pada anak-anak dan juga penyebab setengah dari kematian anak-anak di negara berkembang (Vakili R. 2002, Phengxay M,et al 2007). Malnutrisi dimanifestasikan dengan pola yang berbeda seperti, underweight, stunting, wasting, marasmus kwashiorkor ( Baradaran R et al, 2006). Sejumlah penelitian telah menunjukkan peran penting zat gizi tidak saja pada pertumbuhan fisik tubuh tetapi juga dalam pertumbuhan otak, perkembangan perilaku, motorik, dan kecerdasan (Jalal, 2009; Rapaport R, Bowlby DA,2004; ).

Timbulnya masalah gizi pada anak disebabkan berbagai faktor yang berkaitan antara satu dengan yang lainnya, baik secara langsung maupun tidak langsung. Penyebab langsung yaitu adanya penyakit infeksi dan kurangnya konsumsi makanan dalam keluarga sedangkan penyebab tidak langsung antara lain adalah tidak cukup tersedianya pangan di rumah tangga, semua keadaan ini berkaitan erat dengan rendahnya tingkat pendidikan, tingkat pendapatan dan kemiskinan. yang pada akhirnya mempengaruhi status gizi balita (Kemenkes,2012).

Masih besarnya masalah gizi di Provinsi Nusa Tenggara Timur (NTT) yang termasuk pada masalah kesehatan masyarakat yang kritis (Riskesda,2013),sehingga penelitian ini dilakukan untuk mengetahui faktor - faktor yang mempengaruhi status gizi anak $6-24$ bulan.

\section{BAHAN DAN METODE}

\section{Lokasi dan Rancangan penelitian}

Penelitian ini dilakukan di 9 wilayah Kecamatan (Kuatnana, Batu Putih, Molo Selatan, Soe, Amanuban Barat, Kuanfatu, Amanuban Timur, Polen dan Kualin) di Kabupaten Timur Tengah Selatan Propinsi Nusa Tenggara Timur. Pemilihan lokasi penelitian didasarkan pada daerah binaan WFP yang terdiri dari 3 kecamatan untuk pemberian LNS (KAZIDUTA), 3 Kecamatan untuk pemberian FBF (MP ASI) dan 3 kecamatan sebagai kontrol (bukan daerah binaan WFP). Rancangan penelitian ini adalah cross sectional study.

\section{Populasi Dan Sampel Penelitian}

Populasi pada penelitian ini adalah keluarga yang tinggal di daerah intervensi WFP sebanyak 6 lokasi dan 3 lokasi bukan area WFP pada lokasi penelitian terpilih. Kerangka 
sampel adalah keluarga dengan anak 6 - 24 bulan di lokasi terpilih. Unit sampel pada penelitian ini adalah anak baduta yang stunting.

\section{Cara Pengumpulan Data}

Data konsumsi makanan baduta diperoleh melalui recall konsumsi, sedangkan data lainnya seperti pengukuran antropometri, tingkat pendidikan ibu dan bapak, pekerjaan ibu dan bapak dan lainnya diperoleh melalui kuisioner yang dikumpulkan dengan bantuan tenaga enumerator. Enumerator berasal dari lulusan sarjana kesehatan masyarakat yang telah mendapat pelatihan.

\section{Pengolahan dan Analisis Data}

Pengolahan data dilakukan dengan menggunakan program komputer, yaitu Program Nutrisurvey. Nutrisurvey digunakan untuk mengolah data hasil recall guna memperoleh gambaran asupan zat gizi. Program Nutrisurvey merupakan program khusus yang dirancang untuk mengetahui kandungan zat gizi makanan yang dikonsumsi dalam satuan gram. Program ini mengelompokkan bahan makanan sesuai dengan golongan bahan makanan dan dapat memberikan hasil asupan makanan sesuai dengan jumlah makanan yang dikonsumsi. Data asupan zat gizi selanjutnya dientri dalam program SPSS bersama data-data lainnya seperti pendidikan ibu serta riwayat kesehatan bayi, untuk dianalisis lebih lanjut dengan uji chi square dan untuk mempertajam analisis dilakukan pula uji regresi logistik.

\section{HASIL}

\section{Karakteristik Sosio Demografi Responden}

Jumlah sampel dalam penelitian ini sebanyak 3480 anak yang mengalami stunting dari hasil pengukuran antropometri. Karakteristik anak dan orang tua dapat dilihat pada tabel 1 . Untuk karakteristik anak yang mengalami stunting, sebagian besar anak berumur $12-24$ tahun sebanyak 1916 orang $(55,1 \%)$ dan berjenis kelamin laki - laki sebanyak 1870 orang $(53,7 \%)$. Untuk karakteristik orang tua, baik ibu $(52,5 \%)$ maupun bapak $(49,6 \%)$ berpendidikan dasar $\leq 9$ tahun. Pekerjaan ibu $(79,3 \%)$ dan bapak $(97,8 \%)$ sebagai petani, sementara paritas $\leq 2$ anak $(56,3 \%)$ dan jarak melahirkan > 3 tahun $(62,0 \%)$. Kemudian besar keluarga responden kebanyakan mempunyai anggota keluarga $\leq 4(58,3 \%)$ dengan tingkat sosial ekonomi yang tergolong rendah $(83,5 \%)$.

Tabel 1. Karakteristik Sosial Demografi Anak Stunting 6 - 24 Bulan di Kabupaten Timor Tengah Selatan

\begin{tabular}{lccc}
\hline \multicolumn{1}{c}{ Variabel } & n & \% & P - Value \\
\hline Umur ( bulan ) & 1564 & 44,9 & $0,000^{*}$ \\
$6-11$ & 1916 & 55,1 & \\
$12-24$ & & & \\
\hline
\end{tabular}




\begin{tabular}{|c|c|c|c|}
\hline \multicolumn{4}{|l|}{ Jenis Kelamin } \\
\hline Laki - laki & 1870 & 53,7 & $0,000^{*}$ \\
\hline Perempuan & 1610 & 46,3 & \\
\hline \multicolumn{4}{|l|}{ Pendidikan Ibu } \\
\hline$<9$ tahun & 1827 & 52,5 & $0,000^{*}$ \\
\hline$\geq 9$ tahun & 1653 & 47,5 & \\
\hline \multicolumn{4}{|l|}{ Pendidikan Bapak } \\
\hline$<9$ tahun & 1726 & 49,6 & $0,000^{*}$ \\
\hline$\geq 9$ tahun & 1754 & 50,4 & \\
\hline \multicolumn{4}{|l|}{ Pekerjaan Ibu } \\
\hline Bertani/kerja lainnya & 2761 & 79,3 & $0,000^{*}$ \\
\hline IRT/tidak bekerja & 719 & 20,7 & \\
\hline \multicolumn{4}{|l|}{ Pekerjaan Bapak } \\
\hline Bertani/kerja lainnya & 3405 & 97,8 & 0,093 \\
\hline tidak bekerja & 75 & 2,2 & \\
\hline \multicolumn{4}{|l|}{ Tinggi Ibu } \\
\hline$<150 \mathrm{~cm}$ & 1882 & 54,1 & $0,000^{*}$ \\
\hline$>=150 \mathrm{~cm}$ & 1558 & 44,8 & \\
\hline \multicolumn{4}{|l|}{ Paritas } \\
\hline$>2$ anak & 1520 & 43,7 & $0,041 *$ \\
\hline$\leq 2$ anak & 1960 & 56,3 & \\
\hline \multicolumn{4}{|l|}{ Jarak Kelahiran anak } \\
\hline$\leq 3$ tahun & 1323 & 38,0 & 0,240 \\
\hline$>3$ tahun & 2157 & 62,0 & \\
\hline \multicolumn{4}{|l|}{ Besar Keluarga } \\
\hline$\leq 4$ anggota keluarga & 1451 & 41,7 & $0,037^{*}$ \\
\hline$>5$ anggota keluarga & 2029 & 58,3 & \\
\hline \multicolumn{4}{|l|}{ Sosial Ekonomi } \\
\hline Rendah & 2095 & 83,5 & 0,856 \\
\hline Menengah & 391 & 11,2 & \\
\hline Tinggi & 184 & 5,3 & \\
\hline \multicolumn{4}{|c|}{ Pemberian ASI Eksklusif } \\
\hline Beri ASI & 596 & 17,1 & 0,121 \\
\hline Tidak beri ASI & 392 & 11,3 & \\
\hline
\end{tabular}

\section{Asupan Makan}

Asupan makanan dari hasil recall 24 jam dapat di lihat pada tabel 2. Tingkat konsumsi / asupan makanan dari sumber energy sebanyak 90,3\% yang tidak mencukupi kebutuhan sehari hari sesuai AKG, begitupun dengan asupan protein $(82,6 \%)$, lemak $(97,9 \%)$ dan karbohidrat $(82,0 \%)$. Hasil uji chi-square diperoleh ada hubungan yang signifikan pada asupan makan protein $\mathrm{p}>0,005$.

Tabel 2. Asupan Makanan Anak Stunting 6-24 bulan di Kabupaten Timor Tengah Selatan

\begin{tabular}{lccc}
\hline Aspan Makanan & n & \% & P-Value \\
\hline Kecukupan Asupan Energi & 3144 & 90,3 & 0,116 \\
Tidak Cukup <80\% & 336 & 9,7 & \\
Cukup $\geq 80$ & & & $0,036^{*}$ \\
Kecukupan Asupan Protein & 2876 & 82,6 & \\
Tidak Cukup & 604 & 17,4 & \\
Cukup & & & \\
Kecukupan Asupan Lemak & &
\end{tabular}




\begin{tabular}{lccc}
\hline Tidak Cukup & 3408 & 97,9 & 0,523 \\
Cukup & 72 & 2,1 & \\
Kecukupan Asupan Karbohidrat & & & \\
Tidak Cukup & 2852 & 82,0 & 0,359 \\
Cukup & 628 & 18,0 & \\
\hline
\end{tabular}

\section{Riwayat Penyakit/Morbiditas anak stunting}

Tabel 3, memperlihatkan secara umum riwayat penyakit/morbiditas pada anak stunting dan normal yang diambil pada 2 minggu terakhir relatif tinggi untuk demam $(32,6 \%)$ dengan hasil uji yang signifikan $\mathrm{p}<0,05$, sedangkan diare, batuk, beringus dan sesak dari hasil uji chi square tidak sifnifikan.

Tabel 3. Prvalensi status gizi stunting pada anak 6-24 bulan di kabupaten Soe

\begin{tabular}{lccc}
\hline Riwayat penyakit & $\mathbf{N}$ & $\mathbf{\%}$ & $\mathbf{P}$ \\
\hline Diare & 607 & 17,4 & 0,148 \\
$\quad$ Diare & 2873 & 82,6 & \\
$\quad$ Tidak diare & 1134 & 32,6 & $0,016^{*}$ \\
Demam & 2346 & 67,4 & \\
$\quad$ Demam & & & \\
$\quad$ Tidak demam & 80 & 2,3 & 0,181 \\
$\quad$ Sesak $\quad 3400$ & 97,7 & \\
$\quad$ Sesak & & & 0,209 \\
$\quad$ Tidak sesak & 1078 & 31,0 & \\
$\quad$ Batuk & 2402 & 69,0 & 0,080 \\
$\quad$ Batuk & 1015 & 29,2 & \\
$\quad$ Tidak Batuk & 2465 & 70,8 & \\
$\quad$ Beringus & Beringus & & \\
$\quad$ Beringus tidak beringus & & & \\
\hline
\end{tabular}

*berhubungan signifikan dengan kejadian severe stunting dan stunting, $p<0,005$

\section{Pembahasan}

\section{Karakteristik Sosial Demografi Stunting Anak 6 - 24 Bulan}

Stunting pada anak $6-24$ bulan dalam penelitian ini meupakan prevalensi stunting yang menjadi standar dari WHO, 2010. Ada beberapa faktor yang berhubungan dengan kejadian stunting dalam penelitian ini antara lain : umur anak, jenis kelamin, pendidikan orang tua, pekerjaan orang tua, tinggi ibu, besar keluarga, paritas, jarak kelahiran, sosial ekonomi, pemberian ASI Eksklusif, penyakit infeksi (diare, demam, batuk, sesak dan beringus), asupan makanan.

Jenis kelamin dan umur anak dalam penelitian ini diperoleh ada hubungan dengan kejadian stunting di Kabupaten Timor Tengah Selatan $\mathrm{p}<0,05$, hal ini sejalan dengan hasil penelitian dari Mahgoup, 2006, yang mendapatkan di daerah kumuh Afrika bahwa kejadian stunting secara signifikan lebih umum terjadi pada anak laki - laki dari pada anak perempuan. Demikian pula dengan hasil penelitian Wolde et al 2015, memperoleh bahwa umur anak dapat meningkatkan kejadian stunting dimana faktanya anak yang stunting sejak usia dini 
Health Information: Jurnal Penelitian ISSN xxxx-xxxx

http://myjurnal.poltekkes-kdi.ac.id

akan sulit untuk di rehabilitasi di kemudian hari karena merupakan masalah gizi kronis dan yang paling sering menderita akibat kekurangan gizi ini adalah kelompok umur baduta. Seiring dengan bertambahnya umur disertai dengan adanya asupan zat gizi yang lebih rendah dibandingkan kebutuhan serta tingginya beban penyakit infeksi pada awal-awal kehidupan maka sebagian besar bayi terus mengalami penurunan status gizi dengan puncak penurunan pada umur kurang lebih 18-24 bulan (Donna et al 2002, Babar et al 2010).

Pendidikan memiliki peranan yang sangat penting dalam meningkatkan kualitas hidup seseorang. Pendidikan juga mempengaruhi sepenuhnya terhadap peningkatan ekonomi serta menjadikan manusia lebih cepat mengerti dan siap dalam menghadapi perubahan. Hasil penelitian menunjukkan persentasi terbesar pendidikan ibu $(57,8 \%)$ dan bapak $(57,8 \%)$ adalah pendidikan dasar atau SLTP $\leq 9$ tahun pada anak 6-24 bulan. Hasi uji chi square diperoleh ada hubungan pendidikan bapak dengan kejadian stunting dengan nilai $\mathrm{p}=0,013<$ 0, 05. Hal ini sesuai dengan hasil yang penelitian Biswas et al 2010, De Menezes et al,2011, Abuya AB et al. 2012, yang mendapatkan ada hubungan pendidikan ibu dan bapak dengan kejadian stunting. Anak yang ibunya tidak pernah mengikuti pendidikan formal lebih berpeluang mengalami stunting dibandingkan dengan anak - anak yang ibunya mengikuti pendidikan formal (HS Joshi et al, 2011; BJ Emina et al, 2011 ; Wolde et al, 2015). Kejadian stunting juga mempunyai hubungan yang signifikan dengan pendidikan orangtua ( Mahyar et al, 2010, Ajoa et al, 2010)

Pekerjaan berhubungan dengan pendapatan sehingga dapat mempengaruhi perilaku, dimana semakin baik pekerjaan orang tua biasanya kebiasaan hidup dan norma hidup yang berlaku dikeluarga akan semakin baik dan ini mendorong peningkatan status gizi anak badutanya secara tidak langsung. Pada penelitian ini didapatkan pekerjan ibu dan bapak mayoritas petani (82,3\% dan 65,0\%), hasil uji statistik diperoleh ada hubungan pekerjaan ibu dengan kejadian stunting $\mathrm{p}=0,025$. Hal ini sejalan dengan hasil penelitian Reyes et al, 2004, yang melakukan penelitian di Meksiko memperoleh risiko kejadian stunting di daerah pedesaan lebih besar berhubungan dengan pekerjaan bapak sebagai petani. Jenis pekerjaan merupakan faktor yang dapat menentukan kuantitas dan kualitas pangan yang dibeli karena jenis pekerjaan memiliki hubungan dengan pendapatan yang diterima.

Masalah gizi sesungguhnya bukan hanya berkaitan dengan masalah pangan dan kesehatan, tetap juga berkaitan dengan masalah sosial ekonomi yaitu pendapatan keluarga dimana stunting merupakan cerminan dari keadaan sosial ekonomi suatu masyarakat. Konsumsi pangan keluarga baik dalam jenis maupun jumlah dipengaruhi oleh pendapatan keluarga. 
Health Information: Jurnal Penelitian ISSN xxxx-xxxx

http://myjurnal.poltekkes-kdi.ac.id

Pada penelitian ini didapatkan ada hubungan tingkat sosial ekonomi dengan kejadian stunting $\mathrm{p}=0,022$, hasil ini sesuai dengan hasil penelitian Mahfouz et al 2003 yang memperoleh kejadian stunting berhubungan dengan tingkat sosial ekonomi yang rendah. Semba et al 2008 mendapatkan pendapatan yang rendah dapat mengakibatkan keluarga tidak mampu membeli makanan yang dapat memenuhi kebutuhan sehari - hari baik kualitas maupun kuantitas, begitupun Jenevic et al 2010 yang memperoleh prevalensi stunting berhubungan dengan sosial ekonomi keluarga. Rendahnya pendapatan merupakan salah satu penyebab tidak mampunya membeli pangan dalam jumlah yang cukup, hal ini juga sejalan dengan Lazzi et al 2013, yang juga memperoleh bahwa penyediaan makanan yang kurang dapat meningkatkan kejadian stunting.

Ada hubungan yang signifikan antara besar keluarga dengan kejadian stunting pada anak 6 24 bulan menurut indikator PB/U ( $\mathrm{p}=0.025)$ yang berarti semakin banyak anggota keluarga maka akan semakin buruk status gizi anaknya, hal ini besar kemungkinan akan berdampak terhadap pertumbuhan dan perkembangan anak karena jumlah anak yang banyak akan mengakibatkan selain kurang kasih sayang juga kebutuhan primer seperti makanan dan sandang tidak terpenuhi. Mahyar et al. (2010) dalam penelitiannya yang bertujuan untuk mengetahui faktor determinan underweight, wasting dan stunting anak bawah dua tahun di Iran, ditemukan bahwa ada hubungan yang signifikan antara besar keluarga, urutan kelahiran dan pendidikan orang tua dengan stunting ( $\mathrm{p}<0.05)$. Ajoa et al. (2010) dalam penelitiannya di Nigeria menyimpulkan bahwa prevalensi kurang gizi dalam tingkat rumah tangga disebabkan oleh besarnya jumlah anggota rumah tangga pada keluarga miskin.

\section{Asupan Makronutrien}

Asupan makanan yang tidak memadai dalam 2 tahun pertama bertanggung jawab terhadap kejadian stunting termasuk juga faktor riwayat penyakit infeksi ( Eastwood, 2003).

Jumlah energi yang dibutuhkan seseorang tergantung pada umur, jenis kelamin dan berat badan seseorang. Untuk terpenuhinya kebutuhan zat gizi, seseorang harus makan, bila kurang makan maka kemungkinan seseorang akan kekurangan zat gizi. Hasil penelitian ini tidak ada hubungan yang signifikan antara asupan energy dengan kejadian stunting $(\mathrm{p}=0,388)$, hal ini sejalan dengan hasil penelitian yang dilakukan Gibson et al. (2007) menyebutkan bahwa tidak ada hubungan yang signifikan antara asupan energi dengan stunting $(\mathrm{P}>0,05$.), begitupula THN Tuyet Maj,2003, Wolde et al 2015, mendapatkan tidak ada hubungan yang bermakna antara asupan makronutrien dengan kejadian stunting akan tetapi hasil MD Agrabar $2005^{2}$, yang melakukan penelitian di Meghalaya India Timur Utara menemukan bahwa rata rata asupan energy bermakna signifikan pada anak stunting. 
Health Information: Jurnal Penelitian ISSN xxxx-xxxx

http://myjurnal.poltekkes-kdi.ac.id

Protein merupakan komponen terbesar dari tubuh manusia setelah air. Protein mempunyai fungsi khas yang tidak dapat digantikan oleh zat gizi lain yaitu membangun serta memelihara sel-sel dan jaringan tubuh sehingga erat kaitannya untuk pertumbuhan. Hasil penelitian ini mendapatkan ada hubungan yang signifikan antara kejadian stunting dengan asupan protein $(\mathrm{P}=0,036)$ akan tetapi asupan karbohidrat dan lemak tidak signifikan dengan kejadian stunting $(\mathrm{P}>0,05)$ begitu pula dengan ${ }^{21}$ mendapatkan tidak ada hubungan asupan karbohidrat dengan kejadian stunting. Pada saat ini belum ada didapatkan hubungan antara asupan makanan dengan stunting, hal ini kemungkinan karena stunting merupakan masalah gizi kronis selain itu recall 24 jam tidak mungkin menunjukkan asupann makanan sesorang ${ }^{31}$

\section{Riwayat Penyakit}

Anak baduta sebagai golongan yang rawan, dengan kondisi tubuh yang lemah, akan mudah terserang penyakit menular. Hal ini mengakibatkan semakin lemahnya kondisi tubuh dan kehilangan nafsu makan, sehingga lama kelamaan status gizinya akan memburuk. Adanya penyakit infeksi dapat memperburuk terjadinya stunting. Anak yang menderita penyakit infeksi dapat menyebabkan menurunnya nafsu makan. Hasil uji statistik chi square diperoleh ada hubungan yang signifikan antara demam dengan stunting $(\mathrm{P}<0,05)$ tetapi tidak signifikan dengan diare dan sesak, penelitian ini sejalan dengan hasil penelitian ${ }^{4}$ yang mendapatkan ada hubungan antara demam 6 bulan terakhir dengan stunting. Tingkat keseringan anak menderita penyakit infeksi berdampak pada pertumbuhan linier. Banyak faktor yang mempengaruhi status gizi diantaranya adalah faktor penyebab langsung yang meliputi asupan gizi dan penyakit infeksi. Timbulnya status gizi stunting tidak hanya karena makanan yang kurang tetapi juga karena penyakit. Anak yang mendapat makanan yang cukup baik tetapi sering menderita diare atau demam, akhirnya akan menderita kurang gizi.

\section{Kesimpulan}

Dalam penelitian ini diperoleh faktor determinan stunting adalah usia anak, jenis kelamin, pendidikan ibu dan bapak, pekerjaan ibu, tinggi badan ibu, paritas, jarak kelahiran, asupan protein dan riwayat penyakit demam..

\section{DAFTAR PUSTAKA}




\section{References}

1. Abuya AB et al. 2012. Effect of mother's education on child's nutritional status in the slums of Nairobi. BMC Pediatrics, 12-80.

2. Agrabar Murugkar D,2005. Nutritional status of Khasi schoolgirls in Meghalaya.J Nutr. 2005;21:425-31.

3. Ajoa KO et al. 2010. Influence of Family Size, Household Food Security Status, and Child Care Practices on the Nutritional Status of Under-five Children in Ile-Ife, Nigeria. African Journal Reproductive Health. 14 (4):123.

4. Amany Edward Seedhom, Eman Sameh Mohamed, Eman Mohamed Mahfouz, 2014. Determinants of stunting among preschool children, Minia, Egypt. International Public Health Forum Vol.1 No.2 June 2014.

5. Babar N, Muzaffar R, Khan M, Imdad S, 2010. Impact of socioeconomic factors on nutritional status in primary schoolchildren in Lahore. Pakistan J Ayub Abbottabad. 2010;22(4):15-8.

6. Bhutta ZA, Tahmeed Ahmed, Robert E Black, Simon Cousens, Kathryn Dewey, Elsa Giugliani, Batool A Haider, Betty Kirkwood,Saul S Morris, H P S Sachdev, Meera Shekar.Maternal and Child Undernutrition 3 What works? Interventions for maternal and child undernutrition and survival.The Lancet, Vol 371 February 2, 2008

7. Black RE et al. 2008. Maternal And Child Undernutrition: Global And Regional Exposures And Consequences. www.thelancet.com Vol 371 January 19, 2008.

8. Baradaran R, Hasani K, 2006. Malnutrition in children. Tehran: Iranian Pediatrics Association Publisher; 2006.p.883-886.

9. Biswas S et al. 2010. Sex Differences in the Effect of Birth Order and Parents Educational Status on Stunting: A Study on Bengalee Preschool Children from Eastern India. HOMO-Journal of Comparative Human Biology, 6:271- 276.

10. De Menezes RCE et al. 2011. Determinants Of Stunting In Children Under Five In Pernambuco, Northeastern Brazil. Rev Saúde Pública. 45(6).

11. Donna M, John V, Ann V, Joel D, 2002. Household food security and nutritional status of Hispanic children. Am J Clin Nutr. 2002;76:210-7.

12. Eastwood M. 2003. Principle of Human Nutrition Second Edition. Blackwell Science Ltd, a Blackwell Publishing Company.

13. Emina BJ, Ngianga BK, Joseph I, Yazoume Y,2011. Maternal education and child nutritional status in the Democratic Republic of Congo. J Pub Health Epidemiol. 2011;3:576.

14. Jenevic T et al. 2010. Risk Factors For Childhood Malnutrition In Roma Settlements In Serbia. BMC Public Health. 10:509.

15. Joshi HS, Gupta R, Joshi MC, Mahajan V,2010. Determinants of Nutritional Statusof Schoolchildren, A Cross Sectional Study in the Western Region of Nepal. NJIRM. 2011;2(1):10-5.

16. Kementerian Kesehatan RI, 2013. PenyajianPokok - Pokok Hasil Riset Kesehatan Dasar 2013

17. Kerangka Kebijakan Gerakan Nasional Sadar Gizi dalam Rangka 1000 Hari Pertama Kehidupan (Gerakan 1000 HPK). Republik Indonesia 2012.

18. Lazzi ZS, Das JK, Zahid G, Imdad A, Bhutta ZA., (2013). Impact of education and provision of complementary feeding on growth and morbidity in children less than 2 years of age in developing countries: a systematic review. BMC Public Health. 13 Suppl 3:S13. doi: 10.1186/1471-2458-13-S3-S13. 
19. Mahfouz EM, Mostafa S, Sadek RR, Hathout MH, AwadAllah HI., (2003). Rural/Urban infant nutrition gaps and KAP Of mothers in El Minia and Giza governorate, Egypt. The Egyptian Journal of Community Medicine. 2003; 21 (1): 17-24.

20. Mahgoub SEO et al. 2006. Factors Affecting Prevalence Of Malnutrition Among Children Under Three Years Of Age In Botswana. AJFAND. 6(1).

21. Mahyar A et al. 2010. Prevalence of Underweight, Stunting and Wasting Among Children in Qazvin, Iran. Iranian Journal Of Pediatrick Society. Vol 2, 37-43.

22. Pourhashemi JS, Motlagh GM, Khaniki JRG, Golestan B. Nutritional assessment of Macronutrients in Primary School Children and its Association with anthropometric Indices and Oral Health. Pak J Nutr. 2007;6(6):687-92.

23. Profil Kesehatan Indonesia 2012

24. Rapaport R, Bowlby DA. 2004. Clinical aspects of growth and growth disorder. In: Pescovitsozz OH, Eugster EA. Pediatric endocrinology: Mechanisms, Manifestations and Management. Philadelphia: Lippincott Williams \& Wilkins;.p.172-187.

25. Senbanjo I, Dowu O, Kazeem A, Oshikoya L, Olumuyiwa O, Dusanya O, et al. Prevalence Of and Risk factors for Stunting among School Children and Adolescents in Abeokuta, Southwest Nigeria. J Health Popul Nutr. 2011;29(4):364-70.

26. Reyes et al. 2004. The family as a determinant of stunting in children living in conditions of extreme poverty: a case-control study. BMC Public Health 2004, 4:57.

27. Semba RD et al. 2008. Effect Of Parental Formal Education On Risk Of Child Stunting In Indonesia And Bangladesh: A Cross-Sectional Study. The Lancet. Volume 371, Issue 9609 , pp. $322-328$.

28. Tuyet Maj THN, Kim M, Kawakami VC, Nguyen: Macronutrient intake andnutritional status of primary school girls in South Vietnam. J. Nutr. Sci. Vitaminol 2003;49:13-20.

29. UNHCR. 2011. Operational Guidance on the Use of Special Nutritional Products to Reduce Micronutrient Deficiencies and Malnutrition in Refugee Populations.

30. WHO-The World Bank Joint Child Mortality Estimates. 2012. Levels and trends in child mortality.

31. Wolde Mekides, Yifru Berhan, Alemzewed Chala,2015. Determinants of underweight, stunting andwasting among schoolchildren BMC Public Health , 15:8 , DOI $10.1186 / \mathrm{s} 12889-014-1337-2$ 